\title{
Isolation of flavonoids from Anemopaegma arvense (Vell) Stellf. ex de Souza and their antifungal activity against Trichophyton rubrum
}

\author{
Camila Di Giovane Costanzo, Vanessa Colnaghi Fernandes, Sônia Zingaretti, \\ Rene Oliveira Beleboni, Ana Maria Soares Pereira, Mozart Marins, \\ Sílvia Helena Taleb-Contini, Paulo Sérgio Pereira, Ana Lúcia Fachin*
}

Biotechnology Division, University of Ribeirão Preto, Ribeirão Preto, SP, Brazil

\begin{abstract}
Anemopaegma arvense (Vell) Stellf. ex de Souza belongs to the family Bignoniaceae, and is popularly known as catuaba. To evaluate the cytotoxic and antimicrobial activity of $A$. arvense, fraction $\mathrm{F} 3$ and flavonoids 1 (quercetin 3-O- $\alpha$-L-rhamnopyranosyl-( $1 \rightarrow 6)-\beta$-D-glucopyranoside) (rutin) and flavonoid 2 (quercetin 3-O- $\alpha$-L-rhamnopyranosyl-( $(1 \rightarrow 6)-\beta$-D-galactopyranoside) were isolated from the leaves of this plant. Fraction F3 and flavonoids 1 and 2 exhibited no antibacterial activity. Furthermore, no cytotoxic activity of fraction 3 or flavonoids 1 and 2 was observed against the tumor cells tested. However, analysis of the antifungal activity of flavonoids 1 and 2 revealed minimum inhibitory concentrations of 0.5 and $0.25 \mathrm{mg} / \mathrm{mL}$, respectively, against the Trichophyton rubrum strains tested (wild type and mutant). This study demonstrates for the first time the antifungal activity of isolated flavonoids, validating the same activity for $A$. arvense.
\end{abstract}

Uniterms: Bignoniaceae. Anemopaegma arvense/phytochemistry. Catuaba/phytochemistry. Flavonoids/ antifungal activity. Plant extract/evaluation.

\begin{abstract}
Anemopaegma arvense pertence à família Bignoniaceae, sendo conhecida popularmente como Catuaba. Para avaliação de sua atividade citotóxica e antimicrobiana, a fração cromatográfica F3 e os flavonoides 1 (quercetina 3-O- $\alpha$-L-ramnopiranosil- $(1 \rightarrow 6)-\beta-\mathrm{D}$-glucopiranosídeo) (rutina) e flavonoide 2 (quercetina $3-O$ - $\alpha$-L-ramnopiranosil- $(1 \rightarrow 6)-\beta$-D-galactopiranosídeo) foram isolados das folhas de $A$. arvense. A fração 3 e os flavonoides não apresentaram atividade antibacteriana. Nenhuma atividade citotóxica foi observada para a fração F3 e para os flavonoides, quando avaliados contra as células tumorais em teste. Entretanto, e considerando a atividade antifúngica, o flavonóide 1 apresentou valor de concentração inibitória mínima (CIM) de 0,5 mg/mL, enquanto o flavonóide 2, CIM de 0,25 $\mathrm{mg} / \mathrm{mL}$ contra as cepas selvagem e mutante de Trichophyton rubrum, demonstrando, pela primeira vez, que os flavonoides isolados possuem atividade antifúngica, o que valida a mesma atividade para $A$. arvense.
\end{abstract}

Unitermos: Bignoniaceae/fitoquímica. Anemopaegma arvense/fitoquímica. Catuaba/fitoquímica. Flavonóides/atividade antifúngica. Extrato vegetal/avaliação.

\section{INTRODUCTION}

The family Bignoniaceae comprises about 800 plant species that are found mainly in the Neotropical region (Gentry, 1980). In Brazil, several plants of this family are used in folk medicine as astringent and against fever,

\footnotetext{
*Correspondence: A. L. Fachin. Unidade de Biotecnologia, Universidade de Ribeirão Preto. Av. Costábile Romano, 2201 - 14096-900 - Ribeirão Preto - SP, Brasil. E-mail: asaltoratto@unaerp.br
}

rheumatism, diarrhea, cancer and microbial infections (Pio Côrrea, Penna, 1969; Fenner et al., 2006). Anemopaegma arvense (Vell) Stellf. ex de Souza is a species of the family Bignoniaceae, which is popularly known as "catuaba". Commercially available formulations of this plant are used as aphrodisiac (Manabe et al., 1992). The major components identified in $A$. arvense are flavonoids, catuabins, alkaloids, tannins, and resins (Charam, 1987; Zanolari et al., 2005; Tabanca et al., 2007). Flavonoids are becoming the subject of anti-infective research and many groups have isolated and identified the structures 
of flavonoids with antifungal, antiviral and antibacterial activity (Cushnie, Lamb, 2005).

There is an urgent need to develop new and more effective antifungal drugs because of the increased resistance of fungi to the drugs currently used in clinical practices (Rahalison et al., 1994). Plant secondary metabolites represent a good source of novel antimicrobial molecules. Furthermore, there has been an almost exponential rise in cancer-related mortality over recent years, which has led to an increase in the search for new medicines, including those derived from natural products, able to treat the various types of the diseases (Patocka, 2003; Aziz, 2004; Diwanay et al., 2005).

We investigated the cytotoxic and antimicrobial activity of chromatographic fraction $\mathrm{F} 3$ and flavonoids isolated from $A$. arvense in order to provide better understanding of the biological activities of this plant.

\section{MATERIAL AND METHODS}

\section{Plant material}

Leaves of $A$. arvense (Vell) Stellf. ex de Souza (Bignoniaceae) were collected in Sacramento, MG, Brazil, in August 2007 (IBAMA License No. 02001.005076/201116) and identified by Professor Lúcia G. Lohmann, Department of Botany, São Paulo University. Voucher specimens (N HPMU-1333) were deposited at the herbarium of the Ribeirão Preto University.

\section{Extract preparation and purification}

Dried and pulverized $A$. arvense leaves (100 g) were extracted by maceration with $\mathrm{MeOH}(0.5 \mathrm{~L}$ x 3$)$ at room temperature. After filtration and evaporation of the solvent under reduced pressure, the methanolic extract ( $5 \mathrm{~g}$ ) was chromatographed over a Sephadex LH-20 column ( $3 \times 64 \mathrm{~cm}$ ) using $\mathrm{MeOH}$ as the mobile phase, yielding three fractions: F1 $(177 \mathrm{~mL}), \mathrm{F} 2$ $(122 \mathrm{~mL})$, and F3 $(150 \mathrm{~mL})$. Fraction F3 $(0.7 \mathrm{~g})$, rich in flavonoids, was submitted to preparative HPLC separation on a RP-18 column (Supelcosil ${ }^{\mathrm{TM}} \mathrm{RP}-18$, $250 \times 10 \mathrm{~mm}$ i.d., $5 \mu \mathrm{m}$ ) using a Shimadzu LC10A system coupled to a diode array detector $(280 \mathrm{~nm})$. The following gradient program was used: $\mathrm{MeOH}: \mathrm{H}_{2} \mathrm{O}$ (0-100 min: 0-60\% MeOH; 100-110 min: 60-80\% MeOH; 110-112 min: 80-0\% MeOH; 112-120 min: 0\% MeOH). The flow rate was $2.0 \mathrm{~mL} / \mathrm{min}$ and the sample injection volume was $400 \mu \mathrm{L}$ at a concentration of $100 \mathrm{mg} / \mathrm{mL}$. Six subfractions were obtained after purification. The F3.3 (59 mg) and F3.4 (36 mg) subfractions were pooled and purified on a Sephadex LH-20 column $(2.2 \times 40 \mathrm{~cm})$ using acetone:water $(7: 3, \mathrm{v} / \mathrm{v})$ as the mobile phase, yielding two flavonoids: $1(6 \mathrm{mg})$ and $2(12 \mathrm{mg})$.

\section{Identification of flavonoids}

The identity of the flavonoids was confirmed based on ${ }^{1} \mathrm{H}$ and ${ }^{13} \mathrm{C}$ NMR spectral data and by comparison with the literature (Jaramillo et al., 2011). The position of the interglycosidic linkage was provided by ${ }^{13} \mathrm{C}$ NMR and was confirmed by HMBC and HMQC experiments. ${ }^{1} \mathrm{H}$ NMR (300 MHz) and ${ }^{13} \mathrm{C}$ NMR (75 MHz) spectra were recorded with a Bruker Avance DPX 300 spectrometer in DMSO- $\mathrm{d}_{6}$ using TMS as internal standard. HPLC analysis was performed using a Shimadzu LC10AD vp system equipped with a Supelco LC18 column (Supelcosil ${ }^{\mathrm{TM}} \mathrm{RP}$ $18,250 \times 4.6 \mathrm{~mm}$ i.d., $5 \mu \mathrm{m}$ ) and coupled to a diode array detector, monitored at $340 \mathrm{~nm}$. The following gradient program was used: $\mathrm{MeOH}: \mathrm{H}_{2} \mathrm{O}(0-32 \mathrm{~min}: 10-66 \%$ $\mathrm{MeOH}$; 32-35 min: $66-10 \% \mathrm{MeOH}$; $35-40$ min: $10 \%$ $\mathrm{MeOH})$. The flow rate was $1.0 \mathrm{~mL} / \mathrm{min}$ and the sample injection volume was $20 \mu \mathrm{L}$ at a concentration of $1 \mathrm{mg} / \mathrm{mL}$.

\section{Antimicrobial activity}

\section{Trichophyton rubrum}

The clinical strain of T. rubrum (ATCC MYA3108) was kindly provided by Dr. Nilce M. Martinez-Rossi. The TruMDR2 mutant strain was obtained by disruption of the TruMDR2 gene of strain MYA3108 (Fachin et al., 2006). Standard techniques of manipulation and growth as described previously (Fachin et al., 2001) were used. Susceptibility of the MYA3108 (wild type) and TruMDR2 (mutant) strains was tested by determining the minimum inhibitory concentration (MIC) of fraction F3 and of flavonoids 1 and 2 using the M38-A microdilution technique proposed by the Clinical and Laboratory Standards Institute (CLSI, 2002). Fraction F3 and flavonoids were diluted in 10\% DMSO and the final concentration of DMSO in the antifungal assay was less than $1 \%$. Colonies obtained by growth of the strains on Sabouraud agar plates at $28^{\circ} \mathrm{C}$ for 15 days were harvested by sterile scraping and mixed with sterile saline and the solution was filtered through glass wool. The resulting mixture was transferred to a sterile tube and adjusted spectrophotometrically at a wavelength of $530 \mathrm{~nm}$, ranging from 70 to $75 \%$ transmittance. These conidial suspensions were diluted 1:50 in RPMI 1640 (Sigma, St. Louis, MO, USA) buffered with MOPS, corresponding to twice the density needed for the test of approximately $3-5 \times 10^{5} \mathrm{CFU} / \mathrm{mL}$. Growth, solvent and 
sterility controls were included. Microtiter plates were incubated at $28^{\circ} \mathrm{C}$ for 7 days. The MIC 100 was defined as the lowest concentration of the fraction or flavonoid that resulted in the complete inhibition of fungal growth. The range of concentrations tested was $2.5-0.019 \mathrm{mg} / \mathrm{mL}$ and $0.500-0.019 \mathrm{mg} / \mathrm{mL}$ for fraction $\mathrm{F} 3$ and the flavonoids (1 and 2), respectively. The assays were carried out in triplicate in three independent experiments. Fluconazole and griseofulvin were used as positive controls.

\section{Bacteria}

The following strains were used as test organisms: Staphylococcus aureus (ATCC 6538), Staphylococcus epidermides (ATCC 2228), Escherichia coli (ATCC 25922), and Pseudomonas aeruginosa (ATCC 27853). The antimicrobial activity of fraction F3 and flavonoids 1 and 2 was evaluated using the microdilution method according to CLSI M7-A7 (2006). The test strains were incubated in $\mathrm{BHI}$ medium for $24 \mathrm{~h}$ at $37^{\circ} \mathrm{C}$. The crude extract, fraction F3 and flavonoids were diluted in 10\% DMSO and the final concentration of DMSO in the antibacterial assay was less than $1 \%$. The crude extract and fraction were assayed at concentrations of $2.5,1.25,0.625,0.312,0.156,0.078$, 0.039 , and $0.019 \mathrm{mg} / \mathrm{mL}$. The flavonoids were assayed at a concentration range of 0.500 to $0.039 \mathrm{mg} / \mathrm{mL}$. The assays were carried out in triplicate in three independent experiments. Ampicillin and chloramphenicol were used as positive controls.

\section{Cytotoxic activity}

The following cells were cultured in Dulbecco's modified Eagle's medium (Life Technologies, Inc., Gaithersburg, MD, USA) supplemented with $15 \%$ fetal calf serum (Life Technologies Inc.) at $37^{\circ} \mathrm{C}$ in a humidified atmosphere of $5 \% \mathrm{CO}_{2}: \mathrm{HeLa}$ (human cervix tumor), $3 \mathrm{~T} 3$ (mouse embryonic fibroblasts), and U343MG-a (human glioblastoma cell line). Penicillin (100 U/mL) and streptomycin $(0.1 \mathrm{mg} / \mathrm{mL})$ were added to the medium to prevent bacterial growth. A stock solution $(20 \mathrm{mg} / \mathrm{mL})$ was prepared by dissolving fraction F3 and flavonoids 1 and 2 in $10 \%$ DMSO (v/v). The final concentration of these compounds $(0.2,0.02$ and $0.002 \mathrm{mg} / \mathrm{mL}$, respectively) was obtained by direct dilution in the culture medium. The final concentration of DMSO in the control and experimental groups was $1 \%$. The cells $\left(10^{5}\right.$ cells/well $)$ were seeded into a 96 -well plate $24 \mathrm{~h}$ prior to the beginning of the experiment. Actinomycin D (Sigma) was used as positive control. The cells were incubated for $48 \mathrm{~h}$ with the fraction or flavonoids and analyzed by the MTT assay (Mosmann, 1983; Rubinstein et al., 1990).

\section{RESULTS AND DISCUSSION}

The aglycons were identified as quercetin by ${ }^{1} \mathrm{H}$ and ${ }^{13} \mathrm{C}$ NMR. The ${ }^{1} \mathrm{H}$ NMR spectra indicated the presence of a rhamnosyl and a glucosyl group at $\delta 5.34$ and $\delta$ 4.41 in flavonoid 1 and of a rhamnosyl and a galactosyl group at $\delta 5.30$ and $\delta 4.36$ in flavonoid 2. The relatively deshielded rhamnosyl protons suggested that they are not directly attached to the aglycone, but that there is a sugar-sugar linkage. The position of the sugar in the aglycons provided by HMBC was demonstrated by cross-peaks between H-1" and C-3. The position of the interglycosidic linkage was provided by the ${ }^{13} \mathrm{C}-\mathrm{NMR}$ downfield shift of C-6" at $\delta 67.5$ and $\delta 65.7$ in flavonoids 1 and 2, respectively. This fact was confirmed by HMBC and HMQC experiments. On the basis of the spectroscopic data, flavonoids 1 and 2 were characterized as quercetin 3 - $O$ - $\alpha$-L-rhamnopyranosyl- $(1 \rightarrow 6)-\beta$-D-glucopyranoside (rutin) and quercetin 3-O- $\alpha$-L-rhamnopyranosyl-(1 $\rightarrow 6)$ $\beta$-D-galactopyranoside, respectively (Figure 1). HPLC analysis of fraction $\mathrm{F} 3$ revealed the presence of six flavonoids (Figure 2A). Flavonoids 1 and 2 isolated from A. arvense were detected at 24.1 and $23.2 \mathrm{~min}$, respectively (Figure 2B and 2C).
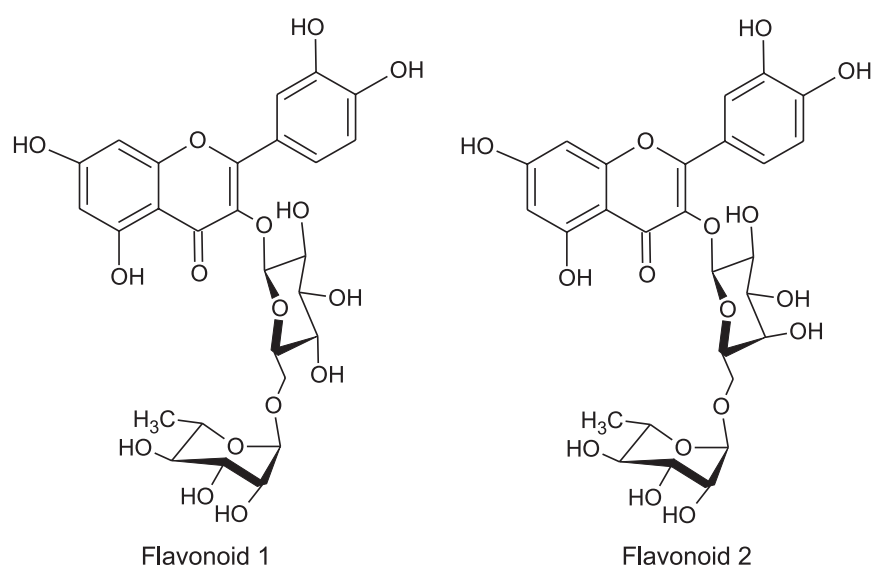

FIGURE 1 - Chemical structure of flavonoids 1 and 2 isolated from Anemopaegma arvense. Flavonoid 1: quercetin 3-O- $\alpha-$ L-rhamnopyranosyl-( $1 \rightarrow 6)-\beta$-D-glucopyranoside (rutin); flavonoid 2 : quercetin $3-O-\alpha$-L-rhamnopyranosyl- $(1 \rightarrow 6)-\beta-\mathrm{D}-$ galactopyranoside.

Analysis of the bioactivity of $A$. arvense showed no cytotoxic activity of fraction $\mathrm{F} 3$ or of the isolated flavonoids at a dose of $0.2 \mathrm{mg} / \mathrm{mL}$ against the cell lines tested. In addition, at a dose of $2.5 \mathrm{mg} / \mathrm{mL}$, the crude extract, fraction F3 and the flavonoids exhibited no antibacterial activity against the strains tested (data not shown). These results partially agree with those reported by Tabanca et al. (2007) 
(A)

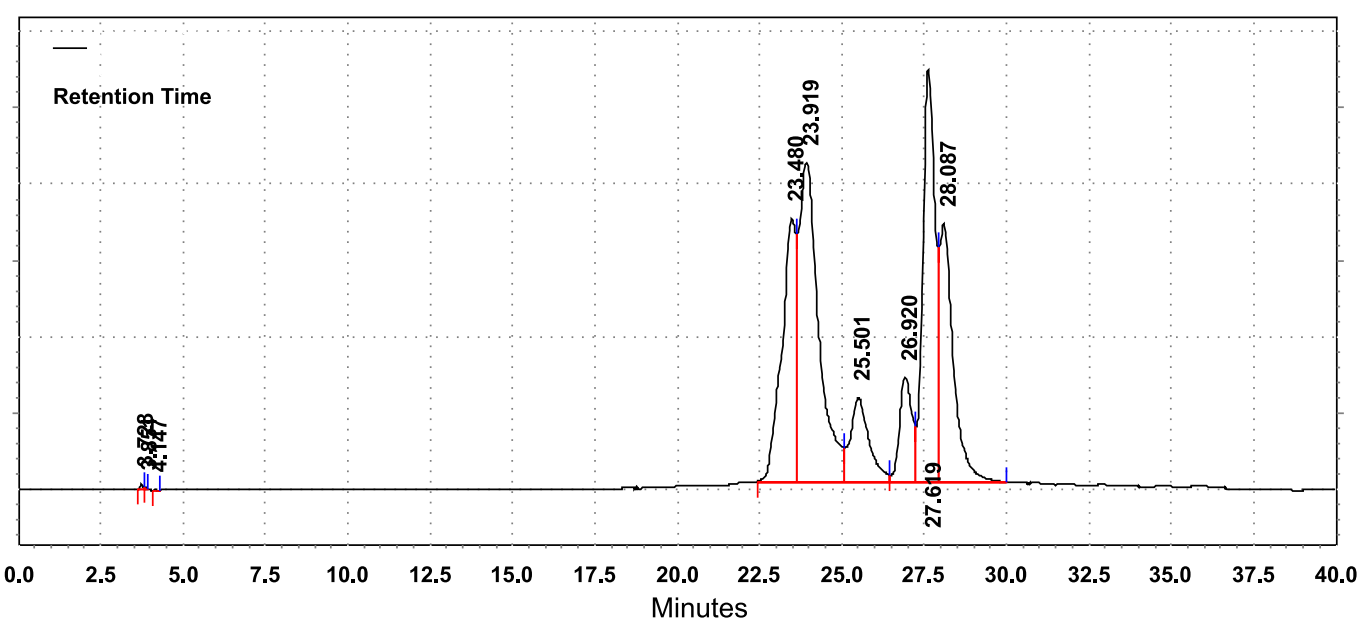

(B)

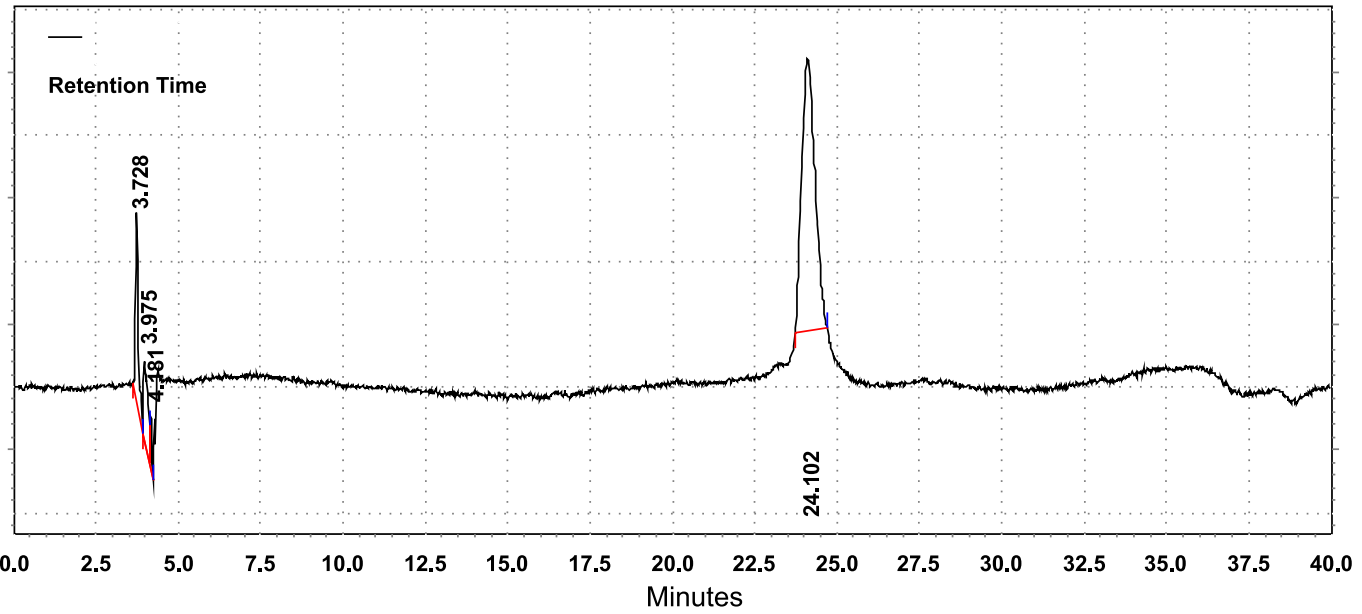

(C)

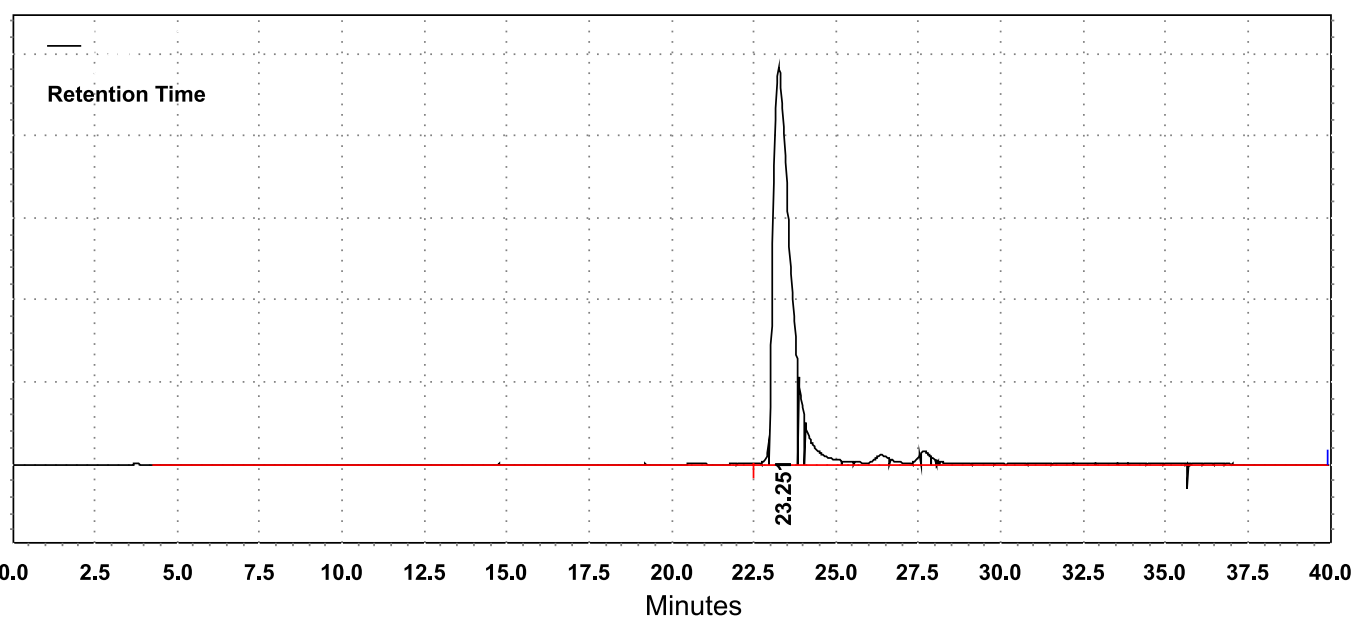

FIGURE 2 - HPLC profile of fraction F3 (A), flavonoid 1 (B), and flavonoid 2 (C) isolated from Anemopaegma arvense.

who isolated a new catuabin (catuabin A) and three known flavan-type phenylpropanoids (cinchonain Ia, cinchonain IIa, and candelin A1) from $A$. arvense. These compounds possessed no anti-inflammatory, cytotoxic, antimicrobial or antimalarial property, but exhibited antioxidant activity.

In the present study, fraction F3 exhibited antifungal activity against the mutant and wild-type strains of
T. rubrum at concentrations of 1.25 and $0.625 \mathrm{mg} / \mathrm{mL}$, respectively. Isolated flavonoid 1 showed weak antifungal activity, with an MIC of $0.5 \mathrm{mg} / \mathrm{mL}$ against the two fungal strains tested, whereas flavonoid 2 exhibited moderate antifungal activity, with an MIC of $0.25 \mathrm{mg} / \mathrm{mL}$ (Table I). Antifungal activity of ethanol extracts of Hyptis ovalifolia and Eugenia uniflora has been demonstrated by Souza et 
al. (2002). These extract completely inhibited the growth of the 30 dermatophytes tested. The MIC of the H. ovalifolia extract against T. rubrum strains was $0.25 \mathrm{mg} / \mathrm{mL}$ and the E. uniflora extract exhibited antifungal activity against 19 of the 30 isolates at a concentration of $0.5 \mathrm{mg} / \mathrm{mL}$. Rocha et al. (2004) demonstrated antifungal activity of Clytostoma ramentaceum and Mansoa hirsuta (Bignoniaceae) when testing the low and medium polar fractions at concentrations of 0.1 to $0.3 \mathrm{mg} / \mathrm{mL}$. Pacciaroni et al. (2008) isolated several flavonoids from the aerial parts of Heterothalamus alienus and tested these compounds against clinical isolates of dermatophytes. The flavanones showed very good fungicidal activity against standard (MIC: $31.2 \mu \mathrm{g} / \mathrm{mL}$ ) and clinical isolates of T. rubrum and T. mentagrophytes (MIC: 31.2-62.5 and 31.2-125 $\mu \mathrm{g} / \mathrm{mL}$, respectively). However, rutin, spathulenol (1) and two of the 3 -acetylated flavanones were inactive or marginally active against the fungal strains (MIC $>250 \mu \mathrm{g} / \mathrm{mL}$ ).

Methods for antimicrobial assessment of natural products and effective MIC values are not well established in the literature. Holetz et al. (2002), who screened hydroalcoholic extracts from 13 Brazilian plants using the microdilution technique, defined an $\mathrm{MIC}<0.1 \mathrm{mg} / \mathrm{mL}$ as good antimicrobial activity, MIC of 0.1 to $0.5 \mathrm{mg} / \mathrm{mL}$ as moderate antimicrobial activity, and MIC of 0.5 to $1 \mathrm{mg} / \mathrm{mL}$ as weak antimicrobial activity. Extracts exhibiting MIC higher than $1 \mathrm{mg} / \mathrm{mL}$ are considered to be ineffective. Reports of activity in the field of antibacterial flavonoid

TABLE I - Minimum inhibitory concentration $(\mathrm{mg} / \mathrm{mL})$ of fraction F3 and flavonoids isolated from Anemopaegma arvense against Trichophyton rubrum strains (MYA-3108 and $\triangle$ TruMDR2)

\begin{tabular}{lcc}
\hline Compound & MYA-3108 & $\Delta$ TruMDR2 \\
\hline Fraction F3 & 0.625 & 1.250 \\
Flavonoid 1 & 0.500 & 0.500 \\
Flavonoid 2 & 0.250 & 0.250 \\
Griseofulvin & 0.0005 & 0.0005 \\
Fluconazole & 0.075 & 0.075 \\
\hline
\end{tabular}

The minimum inhibitory concentration corresponds to the lowest concentration of the fraction or flavonoid that resulted in $100 \%$ inhibition of visible fungal compared to control. The results are representative of three independent experiments performed in triplicate.

Flavonoid 1: quercetin 3- $O$ - $\alpha$-L-rhamnopyranosyl- $(1 \rightarrow 6)-\beta$ D-glucopyranoside (rutin); flavonoid 2: quercetin 3-O- $\alpha-\mathrm{L}-$ rhamnopyranosyl- $(1 \rightarrow 6)-\beta$-D-galactopyranoside.

Fluconazole and griseofulvin were used as positive controls.

Fraction F3: concentration range of 2.5-0.019 mg/mL.

Flavonoids: concentration range of $0.500-0.019 \mathrm{mg} / \mathrm{mL}$. research are widely conflicting, probably because of interand intra-assay variation in susceptibility testing (Cushnie, Lamb, 2005).

Membrane transporters, especially efflux transporters, affect the adsorption and bioavailability of drugs. MIC of flavonoids 1 and 2 was the same for the wild-type and mutant strain of T. rubrum (in which the $\mathrm{ABC}$ gene is disrupted). This finding may be explained by the fact that $\mathrm{ABC}$ transporters are not involved in the transport of flavonoids (Walgren et al., 2000). The TruMDR2 gene was disrupted in the mutant strain of T. rubrum and this strain has been shown to be susceptible to several compounds (Fachin et al., 2006). Therefore, despite relatively high MIC, flavonoid-based inhibitors of fungi may be an alternative for the treatment of multidrug-resistant strains since efflux pumps do not transport these compounds.

In the present study, we were able to isolate and identify two quercetin-derived glycosylated flavonoids from $A$. arvense, which showed antifungal activity. Quercetin is a substance widely distributed in the plant kingdom. However, this study describes for the first time the antidermatophyte activity of $A$. arvense, which could be attributed to the presence of quercetin. In fact, the antifungal activity of quercetin and its derivatives has been described in other medicinal plants. Semwal et al. (2009) demonstrated the antifungal activity of an ethanol extract of Boehmeria rugulosa leaves and of three new flavonoid glycosides against T. rubrum, Microsporum canis and Microsporum gypseum, with MIC of $100 \mu \mathrm{g} / \mathrm{mL}$. Pereira et al. (2008) isolated the flavonoid rutin from the aerial parts of Solanum palinacanthum and evaluation of its antimicrobial activity showed an MIC of $35 \mu \mathrm{g} / \mathrm{mL}$ against the fungus Aspergillus ochraceus.

Human mycoses are not always treated effectively. The most important causes of treatment failure are the recurrence of infections, drug resistance of pathogens, and toxicity of currently available antifungal agents (Turel, 2011; Butts, Krysan 2012). Therefore, the continual search for new and more effective antifungal drugs, which should also be safer than currently used agents, is important (Zacchino, 2001). The increasing prevalence of multidrugresistant pathogens requires the identification of new antimicrobial agents as alternative therapies in difficultto-treat infections (Pereira et al., 2006). In conclusion, the flavonoids isolated from $A$. arvense were bioactive against T. rubrum and may be a promising target in studies on new antifungal agents.

\section{ACKNOWLEDGEMENTS}

The authors thank the state funding agency Fundação 
de Amparo à Pesquisa do Estado de São Paulo (FAPESP) for financial support.

\section{REFERENCES}

AZIZ, Z. Herbal medicines: predictors of recommendation by physicians. J. Clin. Pharm. Ther., v.29, n.3, p.241-246, 2004.

BUTTS A, KRYSAN D.J. Antifungal drug discovery: something old and something new. PLoS Pathog., 8(9):e1002870, 2012.

CHARAM, I. Há ações afrodisíacas nas plantas medicinais do Brasil? Folha Méd., v.94, n.5, p.303-309, 1987.

CLINICAL AND LABORATORY STANDARDS INSTITUTE. In methods for dilution antimicrobial susceptibility tests for bacteria that grow aerobically: approved standard. $7^{\text {th }}$ ed. Wayne: Clinical and Laboratory Standards Institute, 2006. p.19087-1898.

\section{CLINICAL AND LABORATORY STANDARDS} INSTITUTE. In reference method for broth dilution antifungal susceptibility testing of filamentous fungi, approved standard M38-A. Wayne: Clinical and Laboratory Standards Institute, 2002.

CUSHNIE, T.P.; LAMB, A.I. Antimicrobial activity of flavonoids. Int. J. Antimicrob. Agents., v.26, n.5, p.343356,2005 .

DIWANAY, S.; CHISTRE, D.; PATAWARDHAN, B. Immunoprotection by botanical drugs in cancer chemotherapy. J. Ethnopharmacol., v.90, n.1, p.49-55, 2005.

FACHIN, A.L.; CONTEL, E.P.; MARTINEZ-ROSSI, N.M. Effect of sub-MICs of antimycotics on expression of intracellular esterase of Trichophyton rubrum. Med. Mycol., v.39, n.1, p.129-133, 2001.

FACHIN, A.L.; FERREIRA-NOZAWA, M.S.; MACCHERONI JR, W.; MARTINEZ-ROSSI, N.M. Role of the ABC transporter TruMDR2 in terbinafine, 4-nitroquinoline$\mathrm{N}$-oxide (4NQO) and ethidium bromide resistance in Trichophyton rubrum. J. Med. Microbiol., v.55, pt.8, p.1093-1099, 2006.
FENNER, R.; BETTI, A.H.; MENTZ, L.A.; RATES, S.M.K. Plantas utilizadas na medicina popular brasileira com potencial atividade antifúngica. Braz. J. Pharm. Sci., v.42, n.3, p.369-394, 2006.

GENTRY, A.A. Flora neotropical monograph. In: Bignoniaceae. Part I, v.25. New York: The New York Botanical Garden, 1980. v.25, n.2, p.1-130, 1992. p1-150

HOLETZ, F.B.; PESSINI, G.L.; SANCHES, N.R.; CORTEZ, D.A.; NAKAMURA, C.V. Screening of some plants used in the Brazilian folk medicine for the treatment of infectious diseases. Mem. Inst. Oswaldo Cruz., v.97, n.7, p.1027-1031, 2002.

JARAMILLO, K; DAWID , C; HOFMANN, T, FUJIMOTO, $\mathrm{Y}$; OSORIO, C. Identification of Antioxidative Flavonols and Anthocyanins in Sicana odorifera Fruit Peel. J. Agric. Food Chem., v.59, n.3, p 975-983, 2011

MANABE, H.; SAKAGAMI, H.; ISHIZONE, H.; KUSANO, H.; FUJIMAKI, M.; KOMATSU, N.; NAKASHIMA, H.; MURAKAMI, T.; YAMAMOTO, N. Effects of catuaba extracts on microbial and HIV infection. In Vivo, v.6, n.2, p.161-166, 1992.

MOSMANN, T. Rapid colorimetric assay for cellular growth and survival: application to proliferation and cytotoxicity assays. J. Immunol. Methods, v.65, n.1-2, p.55-63, 1983.

PACCIARONI, A.V.; GETTE, M.L.; DERITA, M.; ARIZAESPINAR, L.; GIL, R.R.; ZACCHINO, S.A.; SILVA, G.L. Antifungal activity of Heterothalamus alienus metabolites. Phytother. Res., v.22, n.4, p.524-528, 2008.

PATOCKA, J. Biologically active pentacyclic triterpenes and their current medicine signification. J. Appl. Biomed., v.1, n. $7-12$, p. $7-12,2003$

PEREIRA, E.M.; MACHADO, T.B.; LEAL, I.C.R.; JESUS, D.M.; DAMASO, C.R.A.; PINTO, A.V.; GIAMBIAGIDEMARVAL, M.; KUSTER, A.V.; NETTO DOS SANTOS, K.R. Tabebuia avellanedae naphthoquinones: activity against methicillin-resistant Staphylococcus strains, cytotoxic activity and in vivo dermal irritability analysis. Ann. Clin. Microbiol. Antimicrob., 22,.5:5, 2006. 
PEREIRA, A.C.; OLIVEIRA, D.F.; SILVA, G.H.; FIGUEIREDO, H.C.P.; CAVALHEIRO, A.J.; CARVALHO, D.A.; SOUZA, L.P.; CHALFOUN, S.M. Identification of the antimicrobial substances produced by Solanum palinacanthum (Solanaceae). An. Acad. Bras. Ciênc., v.80, n.3, p.427-432, 2008.

PIO CORRÊA, M.; PENNA, L. Dicionário das plantas úteis do Brasil e das exóticas cultivadas. Rio de Janeiro: Ministério da Agricultura, $1969.765 \mathrm{p}$.

RAHALISON, L.; HAMBURGER, M.; MONOD, M.; FRENK, E.; HOSTETTMANN, K. Antifungal tests in phytochemical investigations: comparison of bioautographic methods using phytopathogenic and human pathogenic fungi. Planta Med., v.60, n.1, p.41-44, 1994.

ROCHA, A.D.; OLIVEIRA, A.B.; FILHO, J.D.S.; LOMBARDI, J.A.; BRAGA, F.C. Antifungal constituents of Clytostoma ramentaceum and Mansoa hirsuta. Phytother. Res., v.18, n.6, p.463-467, 2004.

RUBINSTEIN, L.V.; SHOEMAKER, R.H.;. PAULL, K.D.; SIMON, R.M.; TOSINI, S.; SKEHAN, P.; SCUDIERO, D.A.; MONKS, A.; BOYD, M.R. Comparison of in vitro anticancer-drug-screening data generated with a tetrazolium assay versus a protein assay against a diverse panel of human tumor cell lines. J. Natl. Cancer. Inst., v.82, n.13, p.1113-1117, 1990.

SEMWAL, D.K.; RAWAT, U.; SEMWAL, R.; SINGH, R.; KRISHAN, P.; SINGH, M.; SINGH, G.J.P. Chemical constituents from the leaves of Boehmeria rugulosa with antidiabetic and antimicrobial activities. J. Asian Nat. Prod. Res., v.11, n.12, p.1045-1055, 2009.
SOUZA, L.K.H.; OLIVEIRA, C.M.A.; FERRI, P.H.; SANTOS, S.C.; OLIVEIRA JÚNIOR, J.G.; MIRANDA, A.T.B.; LIÃO, L.M.; SILVA, M.R.R. Antifungal properties of Brazilian cerrado plants. Braz. J. Microbiol., v.33, n.3, p.247-249, 2002.

TABANCA, N.; PAWAR, R.S.; FERREIRA, D.; MORAIS, J.P.; KHAN, S.I.; JOSHI, V.; WEDGE, D.E.; KHAN, I.A. Flavan 3-ol-phenylpropanoid conjugates from Anemopaegma arvense and their antioxidant activities. Planta Med., v.73, p.1107-1111, 2007.

TÜREL O. Newer antifungal agents. Expert Rev. Anti. Infect. Ther. v.9, n.3, p. 325-38, 2011.

WALGREN, R.A.; KARNAKY, K.J.; LINDENMAYER, G.E.; WALLE, T. Efflux of dietary flavonoid quercetin 4'-betaglucoside across human intestinal Caco-2 cell monolayers by apical multidrug resistance-associated protein-2. $J$. Pharmacol. Exp. Ther., v.294, n.3, p.830-836, 2000.

ZACCHINO, S. Estratégia para a descoberta de novos agentes antifúngicos, In: YUNES, R.A.; CALIXTO, J.B.(Eds.) Plantas medicinais sob a ótica da química medicinal moderna. Chapecó: Argos, 2001.p.435-479.

ZANOLARI, B.; GUILET, D.; MARSTON, A.; QUEIROZ, E.F.; PAULO, M.Q.; HOSTETTMANN, K. Methylpyrrole tropane alkaloids from the bark of Erythroxylum vacciniifolium. J. Nat. Prod., v.68, p.1153-1158, 2005.

Received for publication on $13^{\text {th }}$ November 2012 Accepted for publication on $12^{\text {th }}$ April 2013 